\title{
Audit Sistem Informasi Sumber Daya Manusia Pada PT. Intercon Terminal Indonesia Menggunakan Framework COBIT 4.1
}

\author{
Jamal Maulana Hudin ${ }^{1}$, Erika Mutiara ${ }^{2}$, Lis Saumi Ramdhani ${ }^{3}$, Rizal Amegia Saputra ${ }^{4}$ \\ 1,2,3,4 Universitas Bina Sarana Informatika \\ e-mail: 1jamal.jml@bsi.ac.id, ${ }^{2}$ erika.emb@bsi.ac.id, ${ }^{3}$ lis.lud@bsi.ac.id, $\underline{\text { rizal.rga@bsi.ac.id }}$
}

\begin{abstract}
Abstrak
Pengelolaan sumber daya manusia merupakan proses dan struktur hubungan yang mengendalikan dan mengarahkan suatu organisasi perusahaan dalam mencapai tujuan organisasi dengan menambahkan nilai agar teknologi informasi dan prosesnya dapat diseimbangkan dengan risikonya. Diperlukan sebuah evaluasi sumber daya manusia dibidang teknologi informasi untuk mengetahui sejauh mana tingkatan pengelolaan terhadap sumber daya manusia di PT Intercome Terminal Indonesia. Sumber daya manusia dibidang teknologi informasi pada PT Intercome Terminal Indonesia membutuhkan pengembangan dan pengelolaan sesuai dengan harapan organisasi. Melihat terbatasnya sumber daya manusia di bidang teknologi informasi pada PT Intercome Terminal Indonesia sangat terbatas sehingga kegiatan operasional masih belum efektif dan memenuhi sasaran yang diharapkan. Melihat kondisi organisasi yang mengalami terbatas pada sumber daya manusia di bidang teknologi informasi dilakukan evaluasi secara detail dengan menggunakan COBIT 4.1. Dalam melakukan evaluasi sumber daya manusia dengan menggunakan kerangka kerja COBIT yang berfokus pada Domain PO, DS dan ME diharapkan dapat memberikan acuan dan perbaikan yang lebih efektif terhadap organisasi ke depannya.
\end{abstract}

Kata Kunci: Evaluasi, Sumber Daya Manusia Teknologi Informasi, COBIT 4.1

\begin{abstract}
Human resource management is the process and structure of relationships that control and direct a company's organization in achieving organizational goals by adding value so that information technology and its processes can be balanced with the risks. An evaluation of human resources in the field of information technology is needed to determine the extent of management of human resources at PT Intercome Terminal Indonesia. Human resources in the field of information technology at PT Intercome Terminal Indonesia requires development and management in accordance with organizational expectations. Seeing the limited human resources in the field of information technology at PT Intercome Terminal Indonesia is very limited so that operational activities are still not effective and meet the expected targets. Seeing the condition of organizations that experience limited human resources in the field of information technology, a detailed evaluation using COBIT 4.1 is conducted. In evaluating human resources using the COBIT framework that focuses on the PO, DS and ME Domains, it is expected to provide a more effective reference and improvement to the organization going forward.
\end{abstract}

Keywords: Evaluation, Human Resources Information Technology, COBIT 4.1 


\section{Pendahuluan}

Sumber Daya Manusia merupakan suatu hal yang sangat penting dan harus dimiliki dalam upaya mencapai tujuan organisasi atau perusahaan. Sumber daya manusia salah satu faktor yang sangat penting bahkan tidak dapat dilepaskan dari sebuah organisasi, baik institusi maupun perusahaan (Ambarwati, 2017).

Pada hakikatnya, Sumber daya manusia berupa manusia yang dipekerjakan di sebuah organisasi sebagai penggerak, pemikir dan perencana untuk mencapai tujuan organisasi itu. Sumber Daya Manusia adalah individu yang bekerja sebagai penggerak suatu organisasi, baik institusi maupun perusahaan dan berfungsi sebagai aset yang harus dilatih dan dikembangkan kemampuannya (Ambarwati, 2017).

Manusia merupakan sumber daya yang paling penting dan menentukan dalam arah dan perubahan organisasi. Tanpa manusia sebagai penggeraknya, organisasi menjadi kumpulan resources yang tidak berguna. Selain itu, sumber daya manusia menjadi pilar penyangga utama sekaligus penggerak roda organisasi dalam usaha mewujudkan visi-misi dan tujuan organisasi. Dan, persis seperti aspek keuangan, pemasaran, mutu, lingkungan, manajemen, operasional, internal dan eksternal, maka sumber daya manusia juga memerlukan audit untuk memeriksa dan melihat sejauh mana fungsi-fungsi sumber daya manusia dalam organisasi memenuhi azas kesesuaian, efektivitas dan efisiensi di dalam prakteknya untuk mendukung tercapainya tujuan dan sasaran organisasi secara keseluruhan.

PT. Intercon Terminal Indonesia (INTERCON) adalah layanan terminal terintegrasi berfokus pada terminal container kosong, yang bertujuan untuk mencapai standar tertinggi layanan terminal di setiap aspek bisnis dan menjamin layanan prima. INTERCON menggunakan sumber daya terbaik dalam hal sumber daya manusia, teknologi, system manajemen, asset dan menjaga komitmen untuk kualitas, kesehatan, keselamatan, dan lingkungan.

Oleh karena itu, berdasarkan latar belakang di atas, maka penulis melakukan penelitian dengan judul "Audit Sistem Informasi Sumber Daya Manusia Pada PT. Intercon Terminal Indonesia Menggunakan Framework Cobit 4.1".

\section{Metode Penelitian}

a. Definisi Audit

Menurut Angelia, Kristanto \& Setevannus (2018) "suatu pemeriksaan yang dilakukan secara kritis dan sistematis, oleh pihak independen, terhadap laporan keuangan yang telah disusun oleh manajemen, beserta catatan-catatan pembukuan dan bukti-bukti pendukungnya, dengan tujuan untuk dapat memberikan pendapat mengenai kewajaran laporan keuangan tersebut".

Sedangkan, menurut Jourdano, Setiawan \& Noertjahyana (2018) "suatu proses sistematik untuk memperoleh dan mengevaluasi bukti secara objektif mengenai pernyataan-pernyataan tentang kegiatan dan kejadian ekonomi, dengan tujuan untuk menetapkan tingkat kesesuaian antara pernyataan-pernyataan tersebut dengan kriteria yang telah ditetapkan, serta penyampaian hasilhasilnya kepada pemakai yang berkepentingan".

\section{b. Sistem Informasi}

Pengertian Sistem adalah kumpulan dari elemen-elemen yang berinteraksi untuk mencapai suatu tujuan tertentu. Dengan pendekatan sistem kita berhubungan dengan perseorangan, dan kita lebih menekankan perannya di dalam sistem dari pada perannya sebagai suatu keseluruhan individu. Keberhasilan komponenkomponen yang dipertimbangkan secara bersama sebagai suatu sistem mungkin jauh lebih besar daripada jumlah keberhasilan setiap komponen yang dipertimbangkan secara terpisah. Sedangkan pengertian Informasi adalah hasil pengolahan data sehingga menjadi bentuk yang penting bagi penerimanya dan mempunyai kegunaan sebagai dasar dalam pengambilan keputusan yang dapat dirasakan akibatnya secara langsung saat itu juga atau secara tidak langsung pada saat mendatang (Sukmaindrayana \& Sidik, 2017)

\section{c. Sumber Daya Manusia}

Sumber Daya Manusia atau human recources mengandung dua pengertian. Pertama, adalah usaha kerja atau jasa yang dapat diberikan dalam proses produksi. Dalam hal lain SDM mencerminkan kualitas usaha yang diberikan oleh seseorang dalam waktu 
tertentu untuk menghasilkan barang dan jasa. Pengertian kedua, SDM menyangkut manusia yang mampu bekerja untuk memberikan jasa atau usaha kerja tersebut. Mampu bekerja berarti mampu melakukan kegiatan yang mempunyai kegiatan ekonomis, yaitu bahwa kegiatan tersebut menghasilkan barang atau jasa untuk memenuhi kebutuhan atau masyarakat (Ambarwati, 2017).

\section{d. Audit Sistem Informasi}

Proses mengumpulkan dan evaluasi suatu bukti menentukan apakah sistem aplikasi terkomputerisasi menetapkan serta menerapkan sistemnya dalam pengendalian intern secara memadai, terjamin integritas datanya dan penyelenggaraan sistem informasi berbasis computer secara efektif (Susan, 2019)

e. Control Objective for Information and Related Technology (COBIT)

COBIT (Control Objective for Information and Related Technology) adalah kerangka dari best of practices manajemen teknologi informasi ( $\mathrm{TI}$ ) yang membantu organisasi untuk memaksimalkan keuntungan bisnis, serta dapat membantu auditor, user dan manajemen mengelola resiko bisnis dan masalah-masalah teknis dalam organisasi. Framework COBIT disusun oleh Information System Audit and Control Association (ISACA) dan IT Governance Institute (ITGI). COBIT dapat digunakan untuk mengukur level kedewasaan (maturity level) dalam proses $\mathrm{TI}$ dan mengukur kesesuaian antara kebutuhan bisnis dan tujuan $\mathrm{TI}$ dalam organisasi (Zulkarnaen, Wahyudi \& Wijanarko, 2017)

\section{f. Domain COBIT 4.1}

Untuk mengatur TI secara efektif, penting untuk menghargai kegiatan dan risiko dalam TI yang perlu dikelola. Mereka biasanya diperintahkandomain tanggung jawab rencana, bangun, jalankan, dan pantau. DalamKerangka kerja COBIT terdapat domain-domain antara lain:

1. Plan and Organise (PO)

Memberikan arahan untuk pengiriman solusi. Plan and Organise (PO), Domain ini mencakup strategi dan taktik, dan menyangkut identifikasidari cara TI dapat berkontribusi terbaik untuk pencapaian bisnistujuan. Realisasi visi strategis perlu direncanakan, dikomunikasikan dan dikelola untuk perspektif yang berbeda. sebuah organisasi yang tepat serta infrastruktur teknologi harus diberlakukan. Domain ini biasanya membahas hal-hal uang berhubingan dengan pertanyaan manajemen.

2. Acquire and Implement (Al)

Menyediakan solusi dan lolos mereka diubah menjadi layanan. Acquire Dan Implement (Al), Domain ini digunakan untuk mewujudkan strategi TI, solusi TI perlu diidentifikasi, dikembangkan atau diperoleh, serta diimplementasikan dan diintegrasikan ke dalamproses bisnis. Selain itu, perubahan dan pemeliharaan sistem yang ada dicakup oleh domain ini untuk memastikan solusinyaterus memenuhi tujuan bisnis.

3. Delivery and Support (DS)

Menerima solusi dan membuatnya dapat digunakan untuk pengguna akhir. Delivery and Support (DS), Domain ini berkaitan dengan pengiriman yang sebenarnya dari layanan yang dibutuhkan, yang meliputi pengiriman layanan, manajemen keamanan dankesinambungan, dukungan layanan untuk pengguna, dan pengelolaan data dan fasilitas operasional.

4. Monitor and Evaluate (ME)

Memantau semua proses untuk memastikan hal itu arah yang disediakan diikuti. Monitor and Evaluasi (ME), Semua proses TI harus secara teratur dinilai dari waktu ke waktu untuk kualitas dan kepatuhan mereka dengan persyaratan kontrol. Domain inimembahas manajemen kinerja, pemantauan pengendalian internal, kepatuhan terhadap peraturan dan tata kelola.

\section{g. Penelitian Terkait}

Penelitian Terkait yang digunakan dalam penelitian ini adalah berdasarkan kerangka kerja COBIT 4.1(Zuraidah, 2019)

1. Identifikasi Business Goals

Pada tahap ini akan dilakukan analisis tujuan bisnis dari PT INTERCON TERMINAL INDONESIA untuk memperoleh gambaran kemana arah yang akan dituju instansi tersebut, kemudian tujuan bisnis tersebut disesuaikan pandangannya yang sesuai dengan domain yang ada pada framework COBIT 4.1 
2. Identifikasi IT Goals

Pada tahap ini akan diidentifikasi tujuan dari pengembangan teknologi informasi berdasarkan tujuan bisnis instansi yang telah ditentukan sebelumnya. Pada tahap ini tujuan teknologi informasi akan didapatkan dengan cara menghubungkan antara tujuan bisnis dengan tujua teknologi informasi berdasarkan kerangka kerja COBIT 4.1.

3. Identifikasi IT Process

Pada tahap ini akan diidentifikasi proses teknologi informasi yang telah ditentukan sebelumnya. Pada tahap ini proses teknologi informasi akan didapatkan dari keterkaitan antara proses teknologi informasi yang berjalan diinstansi dengan proses teknologi informasi berdasarkan kerangka kerja COBIT 4.1.

4. Control Objectives

Control Objectives merupakan bagian dari detail proses teknologi informasi, dimana tidak semua control objective akan dipakai dalam proses teknologi informasi.

5. Perhitungan Tingkat Kematangan (Maturity Level)

Pada tahap ke lima dari penelitian ini adalah perhitungan maturity level, sesuai dengan maturity model berdasarkan kerangka kerja COBIT 4.1.

h. Tinjauan Organisasi / Objek Penelitian PT. Intercon Terminal Indonesia (INTERCON) di dirikan oleh Bapak Marzuki Alie pada tahun 2017, berfokus pada terminal container kosong. Selama periode ini perusahaan mengembangkan bisnis mereka mulai dari Surabaya dan Terminal Belawan.

INTERCON bertujuan untuk mencapai standar tertinggi layanan terminal di setiap aspek bisnis dan menjamin layanan prima.

INTERCON menggunakan sumber daya terbaik dalam hal sumber daya manusia, teknologi, system manajemen, asset dan menjaga komitmen kami untuk kualitas, kesehatan, keselamatan, dan lingkungan.

Kami berusaha keras untuk meningkatkan dan mengembangkan di setiap aspek untuk memperkuat keberadaan kami untuk mencapai visi kami "Menjadi Pemain Terbesar Layanan Terminal Terpadu di Indonesia".
Visi :

"Menjadi pemain terbesar dalam pelayanan terminal petikemas terpadu di Indonesia dalam waktu 10 tahun".

Misi :

1. Berkomitmen untuk memberikan pelayanan yang terbaik.

2. Mengembangkan bisnis terminal petikemas yang berkelanjutan.

3. Mengembangkan jaringan kerjasama yang menguntungkan.

4. Meningkatkan standar kompetensi sumber daya manusia yang berkelanjutan.

\section{Hasil Penelitian dan Pembahasan}

a. Analisa Data

Pada bab ini akan dijelaskan mengenai hasil dari tahapan Analisa data yang diperoleh secara kualitatif dan kuantitatif yang mencakup penerapan dan pengukuran tingkat kematangan (maturity level) sistem teknologi pada PT. Intercon Terminal Indonesia dengan menggunakan framework COBIT 4.1 dalam tahapan Analisa data tersebut dilakukan dengan cara melakukan penyebaran kuesioner kepada responden yang telah ditentukan untuk mengetahui tingkat kematangan. Berdasarkan identifikasi dengan menggunakan framework COBIT 4.1 dengan domain $\mathrm{PO}$, DS dan ME yang berdasarkan dengan Analisa data yang ditetapkan, yaitu sistem teknologi.

b. Menentukan Key Goal Indicator (KGl) Indikator tujuan utama Key Goal Indicator (KGl) mendefinisikan pengukuran yang menginformasikan kepada manajemen apakah proses sistem teknologi telah mencapai kebutuhan yang telah diinginkan manajemen atau malah sebaliknya.

c. Rekapitulasi Responden

Target responden yang mencakup seluruh Sumber Daya Manusia di PT. Intercon Terminal Indonesia

d. Hasil Kuesioner Tingkat Kematangan (Maturity Level)

Dari pelaksanaan survei untuk menentukan maturity level dengan mengacu kepada responden, sehingga memperoleh jawaban atas kuesioner tersebut sebanyak jumlah kuesioner yang didistribusikan kepada responden. Dengan 
itu di dapatkanlah hasil jawaban responden tersebut. Maka dibuatlah satu rekapitulasi yang secara garis besar dapat memberikan gambaran kecenderungan suatu tingkatan, dengan penerapan sistem penggajian tersebut apakah sudah memenuhi standar indeks kematangan.

Tabel 1. Rekapitulasi hasil PO6

Communicate management aims and direction

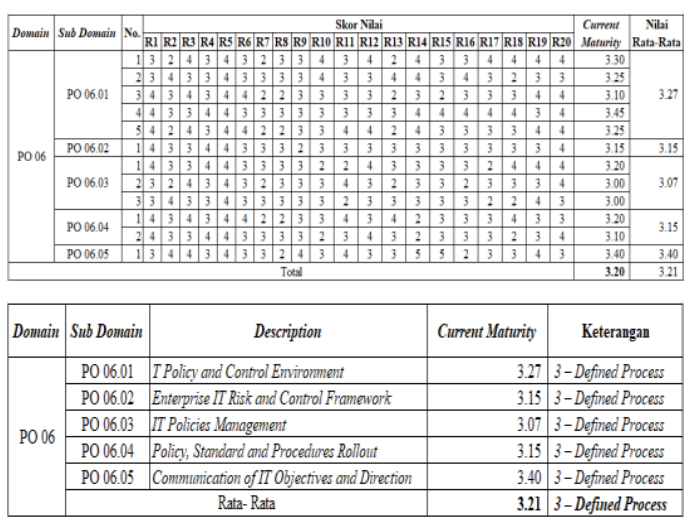

Tabel 2. Rekapitulasi hasil PO7 Manage IT human resources
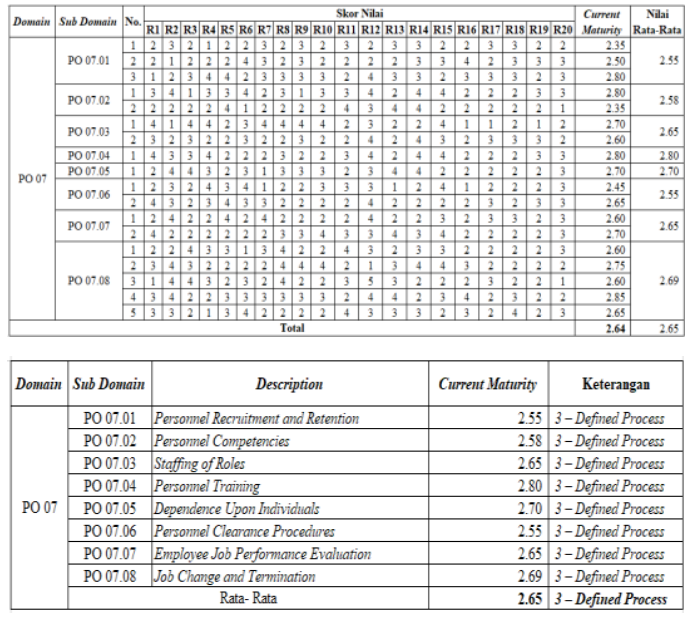

Tabel 3. Rekapitulasi hasil PO8 Manage quality

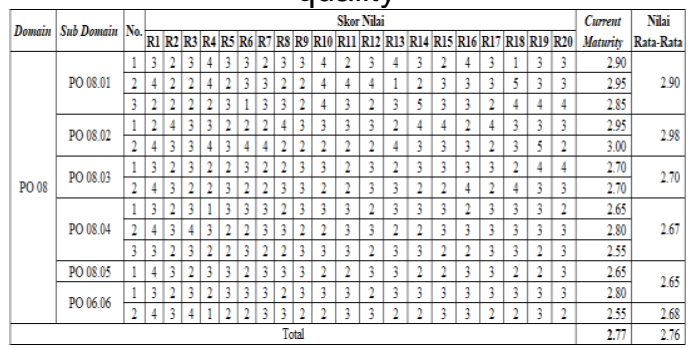

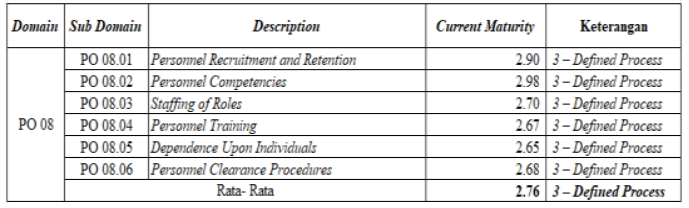

Tabel 4. Rekapitulasi hasil DS7 Educate and train users

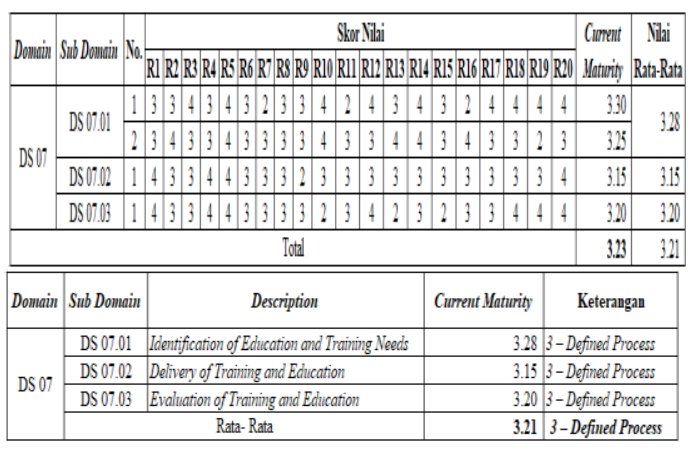

Tabel 5. Rekapitulasi hasil ME1 Monitor and evaluate IT Performance

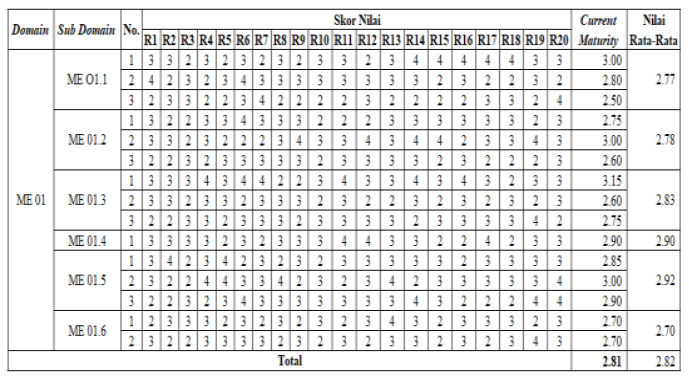

\begin{tabular}{|c|c|c|c|c|}
\hline Domain & Sub Domain & Description & Current Maturity & Keterangan \\
\hline \multirow{7}{*}{$\mathrm{ME} 01$} & ME 01.1 & Monitoring Approach & 2.77 & 3-Defined Process \\
\hline & ME 012 & Defruition and Collection of Monitoring Data & 2.78 & 3-Defined Process \\
\hline & ME 01.3 & Monitoring Method & 2.83 & 3-Defined Process \\
\hline & ME 01.4 & Performance Assessment & 290 & 3-Defined Processs \\
\hline & ME 01.5 & Board and Executive Reporting & 292 & 3-Defined Process \\
\hline & ME 01.6 & Remedial Ictions & 2.70 & 3-Defined Process \\
\hline & & Rata-Rata & 2.82 & 3-Defined Process \\
\hline
\end{tabular}

Tabel 6. Rekapitulasi hasil ME2 Monitor and evaluate internal control

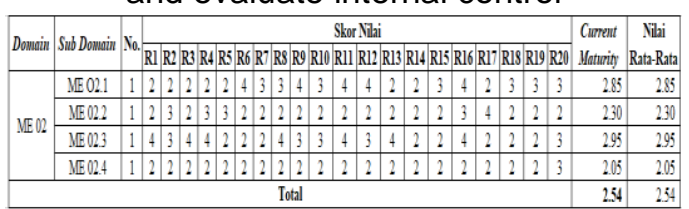

\begin{tabular}{|c|c|c|c|c|}
\hline Domain & Sub Domain & Description & Current Maturity & Keterangan \\
\hline \multirow{5}{*}{ NE 02} & ME 02.1 & Monitoring of Internal Control Framework & 285 & 3-Defined Process \\
\hline & $\mathrm{ME} 02.2$ & Sipenisoly Review & 230 & 2-Repeatable But Intitifive \\
\hline & ME 023 & Control Exceptions & 295 & 3-Defined Processs \\
\hline & ME 024 & Control Self-assessmment & 205 & 2-Repeatable Buit Initifitive \\
\hline & & Rata-Rata & 2.54 & 3-Defuled Process \\
\hline
\end{tabular}


e. Perhitungan Semua Maturity Level

Dari hasil audit sistem informasi teknologi di atas, maka sub domain rata rata hasil perhitungan maturity level, diperlihatkan pada tebel berikut :

\begin{tabular}{|c|r|c|c|}
\hline Domain & Current Maturity & Expected Maturity & Keterangan \\
\hline P06 & 3.21 & 3 & 3 -Defined Process \\
\hline P07 & 2.65 & 3 & 3 -Defined Process \\
\hline P08 & 2.76 & 3 & 3 -Defined Process \\
\hline$D S 7$ & 3.21 & 3 & 3 -Defined Process \\
\hline ME1 & 2.82 & 3 & 3 -Defined Process \\
\hline ME2 & 2.54 & 3 & 3 -Defined Process \\
\hline Rata-Rata & 2.87 & 3 & 3 -Defined Process \\
\hline
\end{tabular}

Keseluruhan maturity yang di rataratakan adalah pada level 3 yaitu defined process. Dengan data yang ada pada table IV.22 rata-rata perhitungan Maturity Level, maka dibuat gambarnya menggunakan diagram batang, diperlihatkan pada gambar di bawah ini :

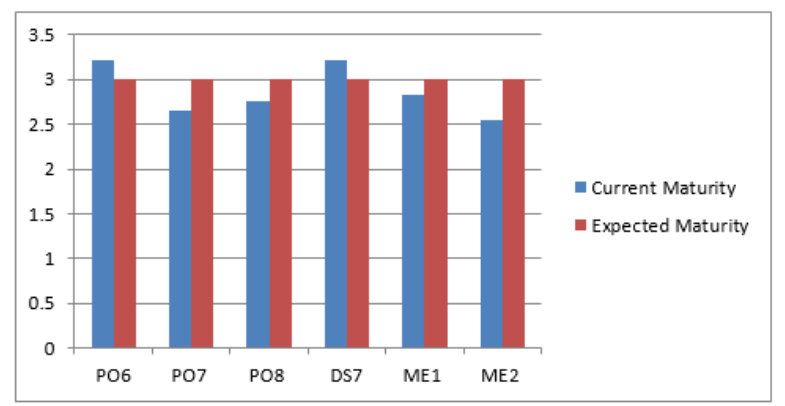

\section{Kesimpulan dan Saran}

a. Kesimpulan

1) Rekapitulasi hasil dari domain PO6 (Communicate management aims and direction) nilai rata-ratanya $3.21, \mathrm{PO} 7$ (Manage IT human resources) nilai rataratanya 2.65, PO8 (Manage quality) nilai rata-ratanya 2.67. Rekapitulasi hasil DS7 (Educate and train users) nilai rataratanya 3.21. Dan Rekapitulasi hasil ME1 (Monitor and evaluate IT Performance) nilai rata-ratanya 2.82 , ME2 (Monitor and evaluate internal control) nilai rata-ratanya 2.54 .

2) Jadi dapat di simpulkan hasil pengolahan kuisioner mendapati nilai rata-rata untuk domain $\mathrm{PO}$, DS dan ME adalah 2.87 dari rentang nilai 0 sampai 5. Artinya PT. Intercon Terminal Indonesia telah menerapkan teknologi informasi pada level Defined Process dan melakukannya dengan baik.

b. Saran
1) Langkah pertama yang harus dilakukan oleh perusahaan dalam memperbaiki TInya adalah meningkatkan pada subdomain PO6, PO7, PO8, DS7, ME1, dan ME2 sesuai rekomendasi yang telah diberikan oleh penulis.

2) Mempersiapkan SDM yang memadai, melakukan transfer pengetahuan dari ahli kepada staf lain melalui pelatihan atau kursus mencakup bidang-bidang yang menggunakan teknologi informasi dalam proses bisnis, memberikan pelatihan dalam pengelolaan resiko.

3) Meningkatkan system teknologi informasi sumber daya manusia dalam bidang Monitor and evaluate internal control agar tercapainya kesejahteraan baik bagi perusahaan maupun pegawainya.

\section{REFERENSI}

Ambarwati. (2017). Audit Manajemen Fungsi Sumber Daya Manusia Padapt. Landipo Niaga Raya Kendari. Jurnal Akuntansi (JAk), Vol. 2 No. 1(ISSN: 2503-3069).

Angelia, M., Kristanto, Setevannus, Y., \& Andry, J. F. (2018, Agustus ). Audit Sistem Informasi Absensi Pada PT. Sinar Pratama Agung Menggunakan Kerangka Kerja COBIT 4.1. Jurnal Ilmiah Rekayasa dan Manajemen Sistem Informasi, Vol. 4, No. 2(eISSN 2502-8995, p-ISSN 24608181), 163-171.

Jourdano, G. V., Setiawan, A., \& Noertjahyana, A. (2018). Audit Sistem Informasi Menggunakan Framework COBIT 4.1 (Dengan Domain Monitor and Evaluate) Pada PT. Samudera Indonesia Tbk. Jurnal Infra, Vol. 6 No.1, 87-194.

Sukmaindrayana, A., \& Sidik, R. (2017). Aplikasi Grosir Pada Toko RSidik Bungursari Tasikmalaya. Jurnal Manajemen Informatika (JUMIKA), Vol 4 No. 2 (2017)(ISSN : 2338-1477 - EISSN : 2541-6375), 31-40.

Susan, E. (2019, Agustus). Manajemen Sumber Daya Manusia. Jurnal Manajemen Pendidikan Islam, Vol. 9 No. 2(P-ISSN: 2407-8107 E-ISSN: 2685-4538), 952-962.

Zulkarnaen, D. R., Wahyudi, R., \& Wijanarko, A. (2017, Agustus ). Audit Sistem Informasi Pada Rumah Sakit Umum Daerah Banyumas 
Menggunakan Framework Cobit 4.1.

Jurnal Pro Bisnis, Vol. 10 No. 2 (ISSN : 1979 - 9258 e-ISSN : 2442 4536), 27-37.

Zuraidah, E. (2019, September). Audit Sistem Informasi Sumber Daya Manusia Menggunakan COBIT 4.1 pada Perusahaan Sparepart mobil PT. XYZ di Jakarta. Jurnal PROSISKO, Vol. 6 No.2(e-ISSN: 2597-9922, p-ISSN: 2406-7733), 96101. 